Review

\title{
Teleost intestinal immunology
}

\author{
Jan H.W.M. Rombout ${ }^{\text {a,b,*}}{ }^{\text {, Luigi Abelli }}{ }^{c}$, Simona Picchietti ${ }^{d}$, Giuseppe Scapigliati ${ }^{d}$, Viswanath Kiron ${ }^{\text {b }}$ \\ ${ }^{a}$ Cell Biology and Immunology Group, Wageningen Institute of Animal Sciences, Wageningen University, Wageningen, The Netherlands \\ ${ }^{\mathrm{b}}$ Faculty of Biosciences and Aquaculture, Bodø University College, Bodø, Norway \\ ${ }^{c}$ Department of Biology and Evolution, Section of Comparative Anatomy, Ferrara University, Ferrara, Italy \\ d Department of Environmental Sciences, Tuscia University, Viterbo, Italy
}

\section{A R T I C L E I N F O}

\section{Article history:}

Received 15 July 2010

Received in revised form

24 August 2010

Accepted 2 September 2010

Available online $\mathrm{xxx}$

\section{Keywords:}

Teleost

Gut associated lymphoid tissue

Mucosal immunity

Oral vaccination

Probiotics

Enteritis

\begin{abstract}
A B S T R A C T
Teleosts clearly have a more diffuse gut associated lymphoid system, which is morphological and functional clearly different from the mammalian GALT. All immune cells necessary for a local immune response are abundantly present in the gut mucosa of the species studied and local immune responses can be monitored after intestinal immunization. Fish do not produce IgA, but a special mucosal IgM isotype seems to be secreted and may (partly) be the recently described IgZ/IgT. Fish produce a pIgR in their mucosal tissues but it is smaller (2 ILD) than the 4-5 ILD pIgR of higher vertebrates. Whether teleost pIgR is transcytosed and cleaved off in the same way needs further investigation, especially because a secretory component (SC) is only reported in one species. Teleosts also have high numbers of IEL, most of them are CD3- $\varepsilon^{+} / \mathrm{CD} 8-\alpha^{+}$and have cytotoxic and/or regulatory function. Possibly many of these cells are TCR $\gamma \delta$ cells and they may be involved in the oral tolerance induction observed in fish. Innate immune cells can be observed in the teleost gut from first feeding onwards, but B cells appear much later in mucosal compartments compared to systemic sites. Conspicuous is the very early presence of putative T cells or their precursors in the fish gut, which together with the rag-1 expression of intestinal lymphoid cells may be an indication for an extra-thymic development of certain $\mathrm{T}$ cells. Teleosts can develop enteritis in their antigen transporting second gut segment and epithelial cells, IEL and eosinophils/basophils seem to play a crucial role in this intestinal inflammation model. Teleost intestine can be exploited for oral vaccination strategies and probiotic immune stimulation. A variety of encapsulation methods, to protect vaccines against degradation in the foregut, are reported with promising results but in most cases they appear not to be cost effective yet. Microbiota in fish are clearly different from terrestrial animals. In the past decade a fast increasing number of papers is dedicated to the oral administration of a variety of probiotics that can have a strong health beneficial effect, but much more attention has to be paid to the immune mechanisms behind these effects. The recent development of gnotobiotic fish models may be very helpful to study the immune effects of microbiota and probiotics in teleosts.
\end{abstract}

(c) 2010 Elsevier Ltd. All rights reserved.

\section{Introduction}

In the last decades mucosal immunology of more evolved vertebrates is a strongly explored field of research. Although a well functioning mucosal immune system in fish would be very beneficial to live in a pathogen rich aquatic environment, not many details are known about this system in this group of animals. This review will summarize the data known about the intestinal

\footnotetext{
* Corresponding author. Cell Biology and Immunology Group, Wageningen Institute of Animal Sciences, PO Box 338, $6700 \mathrm{AH}$ Wageningen, The Netherlands. Fax: +31 317482718

E-mail address: jan.rombout@wur.nl (J.H.W.M. Rombout).
}

immune system of teleosts and when appropriate will compare it with the mammalian intestinal immune system.

In mammals two sites can be distinguished with respect to the gut mucosal immune system: the induction sites (GALT structures like Peyer's patches) and the effector sites: lamina propria (LP) and the intraepithelial lymphocyte (IEL) compartment [1,2]. Very essential in the follicle-associated epithelium above the induction sites are the $M$ cells that can actively transport exogenous antigens to the underlying lymphoid tissue and finally can result in IgA class switching [3] and the secretion of high amounts of dimeric IgA at the effector sites $[1,2]$. The secreted IgA is subsequently bound by the polymeric Ig receptor (pIgR) and transcytosed to the intestinal lumen or to the bile in the liver. The extracellular part of the receptor is then cleaved off and secreted as secretory component

1050-4648/\$ - see front matter (c) 2010 Elsevier Ltd. All rights reserved. doi:10.1016/j.fsi.2010.09.001 